\title{
Transference Love and Countertransference Love in Clinical Technique
}

\author{
Ronald J. Koshes, M.D. \\ Uniformed Services University of the Health Sciences, Fort Lee, Virginia \\ Colleen E. Sari, M.D. \\ Uniformed Services University of the Health Sciences, Fort Lee, Virginia
}

Follow this and additional works at: https://jdc.jefferson.edu/jeffjpsychiatry

Part of the Psychiatry Commons

Let us know how access to this document benefits you

\author{
Recommended Citation \\ Koshes, M.D., Ronald J. and Sari, M.D., Colleen E. (1991) "Transference Love and Countertransference \\ Love in Clinical Technique," Jefferson Journal of Psychiatry. Vol. 9 : Iss. 1 , Article 7. \\ DOI: https://doi.org/10.29046/JJP.009.1.005 \\ Available at: https://jdc.jefferson.edu/jeffjpsychiatry/vol9/iss1/7
}

This Article is brought to you for free and open access by the Jefferson Digital Commons. The Jefferson Digital Commons is a service of Thomas Jefferson University's Center for Teaching and Learning (CTL). The Commons is a showcase for Jefferson books and journals, peer-reviewed scholarly publications, unique historical collections from the University archives, and teaching tools. The Jefferson Digital Commons allows researchers and interested readers anywhere in the world to learn about and keep up to date with Jefferson scholarship. This article has been accepted for inclusion in Jefferson Journal of Psychiatry by an authorized administrator of the Jefferson Digital Commons. For more information, please contact: JeffersonDigitalCommons@jefferson.edu. 


\title{
Transference Love and Countertransference Love in Clinical Technique ${ }^{1}$
}

\author{
Ronald J. Koshes, M.D. ${ }^{2}$ \\ Colleen E. Sari, M.D.
}

\begin{abstract}
The authors review the original and modern concepts of transference and countertransference love as described by Sigmund Freud followed by the more recent theories of Heinz Kohut and Otto Kernberg, focusing on dynamic clinical importance. Case examples are presented to illustrate the important clinical presentations, problems and pitfalls as well as techniques of managing the eroticized transference. The countertransference implications are especially explored as well as indications for supervision.
\end{abstract}

\section{INTRODUCTION: HISTORICAL PERSPECTIVES}

In 1915, Freud wrote that the phenomenon of love between patient and therapist was of dynamic clinical importance, and we would add, an essential ingredient to successful treatment. Freud wrote: "What I have in mind is the case in which a woman patient shows by unmistakable indications, or openly declares, that she has fallen in love, as any other mortal woman might, with the doctor who is analyzing her. This situation has its distressing and comical aspects, as well as its serious ones" (1).

If this love occurs within the context of the transference, then the phenomenon is termed transference love. As can be expected, the therapist's love feelings within the context of the countertransference is termed countertransference love. Perhaps the most lively description of the onset of the transference, and by consequence, the transference love, is given by Glover (2). He relates that instead of talking about the past, the patient tries to focus on the present; this heralds the emergence of the transference neurosis. He states: "The more frequent silences are punctuated by nervous, feathery coughs and throat clearings: the speech hesitates more, as if the patient's throat and lips are dry; the muscles stiffen a little; the couch posture becomes more rigid and wary, and numerous other minor indications appear to show that under the surface the patient is reacting to the current analytic situation. For the first time anxiety attacks may present themselves on the way to analysis ... the

\footnotetext{
'A version of this paper was presented at the Burroughs-Wellcome workshop "Love: A Four Letter Word in Psychiatry" during the annual meeting of the American Psychiatric Association, San Francisco, May, 1989.

${ }^{2}$ Corresponding author.
} 
patient ... intimates that there is nothing else on his mind. Moreover, he usually expresses the view that it is time the analyst did some talking."

Freud stated that the transference love itself often occurs "precisely at the point of time when one is having to try to bring her (the patient) to admit or remember some particularly distressing and heavily repressed part of her life-history". He says the transference love is the resistance which staves off the continuation of the treatment and therefore insight. ".... (T)he patient's endeavor to assure herself of her irresistibility, to destroy the doctor's authority by bringing him down to her level of a lover and to gain all the promised advantages incidental to the satisfaction of love". He called this abnormal love since it was provoked by the analytic situation and was intensified by resistance (3).

The history of the concept of transference love is rooted in an understanding of what Freud and others meant by transference neurosis, or the initial phase of the transference phenomenon. In his "A Short Annotation to Sigmund Freud's 'Observations on Transference Love' ", Eichhoff ponders how the development of a transference neurosis sets the stage for the transference love. He states that the transference neurosis is more than an intrapsychic process, which results from the "collaboration between the patient and the analyst in the role of co-authors." He believes that the issue of transference neurosis and specifically transference love can be understood in terms of separation and individuation; the birth of the transference phenomenon is an attempt to master a trauma by active repetition. "(C)oncretization in the form of an insistence on the reality of love and hate in the transference probably have the aim of restitution and stabilization of a damaged or insufficiently consolidated representation of self and object" (4).

Freud's later writings clearly describe the transference neurosis as an emergence of disguised early conflicts in the here-and-now therapeutic situation. He states that "(e)arly infantile conflicts have gone underground and the work of the patient is presently concentrated on the conflicts he experiences in the analysis with the therapist." Essentially, Freud saw the development of transference as a consequence in neurotic individuals of the frustrated demand for love. He said, "If someone's need for love is not entirely satisfied by reality, he is bound to approach every new person whom he meets with libidinal anticipatory ideas." Therefore, it is to be expected, reasoned Freud, that some portion of this libido is directed at the analyst. Transference neurosis is helped in its development by the ungratified instinctual demands of the analytic situation (5).

By the middle of the century, however, the concept of transference love became absorbed in discussions of transference psychosis, delusional transference, erotic, or eroticized transference; Freud's original transference love was deemed as a special form of transference. Central to the notion of eroticized transference is the position of the patient vis a vis the analyst: "in the transference situation, the analyst is seen as if he were the parent, while in erotization of the transference, he is the parent. The patient does not even acknowledge the 'as if" "' (6). In general, transference love is a defense of the analysis of the patient's illness and it manifests in the real-life relationship of the therapist and patient. Part of the transference neurosis, this love 
develops as the therapist hold a neutral posture and the patient's childhood experiences merge with the present in an enactment of old ego attitudes in response to the analyst as the parent or love object (7). Fenichel more eloquently states in 1941, that the transference neurosis is acting out in the analysis to avoid the development of insight (8). On a positive note, Alexander and French describe the transference neurosis as a process of active "immunization;" the patient is exposed in small does to previously unmastered emotional tensions which he is now helped to master (9).

In the following case example, we see how the patient communicates to the therapist his developing transference neurosis and hence, transference love. Also, we see how the therapist feels in response to this.

\section{CASE EXAMPLE 1}

Mr. S.F. is a 43 year old man who sought individual therapy after trying couples therapy with his wife. He said he did not feel comfortable with his wife present during sessions. After a few months of individual work, he told both his wife and his therapist, a female third-year resident, that he had decided to end an affair he had been having with his wife's best friend. $\mathrm{He}$ explained that the reason he could stop seeing the other woman was that the therapist now supplied everything that he had wanted from the affair. Each session was highly charged with his eroticized fantasies about the therapist. She reports that turning the "Therapy In Progress" sign on her office door at the beginning of the session felt equivalent to hanging a "Do Not Disturb" sign on a motel room.

The emergence of the transference love is coupled with the patient decreasing his acting out behavior, and predicts a good treatment outcome.

\section{WORKING THROUGH TRANSFERENCE LOVE}

Freud instructs the therapist to talk about, but do not act on the intensity of the transference neurosis and hence the transference love. Indeed, physical love in a therapeutic relationship can ruin therapy and destroy careers and families. He draws our attention to the feelings of love in the therapist as an awakening of infantile incestuous wishes. On the other hand to urge the patient to suppress these feelings of love arising in the patient is to cause the patient to feel humiliation which would kindle revenge. In this instance, the therapy may no longer be an opportunity for exploration but rather a defensive stand-off. Freud's statement is clear; "the treatment must be carried out in abstinence" (10). The formula he presents for working through the transference love is an acceptance of the phenomenon on the part of the therapist and a continued curiosity in exploring the patient's current feelings as an acted out memory of past events.

\section{MODERN CONCEPTS OF TRANSFERENCE LOVE}

More recently Kohut and has added to our understanding of transference and countertransference love. His major thesis, although still somewhat controversial among analysts, is that the transference experience is an attempt at protection of the 
cohesive self. Central to Kohut's theories is the notion of idealization which is essential in normal narcissistic development. During the primitive stages of object relations and formation of the self, libidinal cathexes may in some way be traumatized. Characterological aspects of the parental interaction, not just separations and losses, were at the root of the intense transference reactions during therapy. In the transference neurosis, the idealized parental imago becomes projected onto the therapist. The patient must keep the analyst in a state of this idealization (idealizing transference) in order to protect both against anger and intensified longings which are directed towards the therapist. In this way, the transference neurosis protects against fragmentation of the self. Kohut writes, "( $t$ )he therapist's attention effectively counteracts the tendency towards fragmentation and discontinuity of the patient's self-experience, solidifying his self-esteem and thus secondarily improving his ego functioning and efficiency" (11).

Kernberg (12) however would argue that this idealizing transference is a manifestation of splitting rather than a protection against fragmentation of the self. He sees this as more pathological than adaptive. For sure, both Kohut and Kernberg view the idealizing transference as a defensive stance. The transference love Freud described is a warm, object-related position more common in the neurotic patient capable of whole object relations as opposed to fragmentary part-object relations.

The intense idealizing transference or love of the therapist is also a way to protect the patient against disappointment. Changes in the therapist's mood, location or tension are of utmost importance. The temporary withdrawal on the part of the analyst by vacation, or sickness, or by change in attitude, will precipitate in the patient a narcissistic rage. In the normal experience of love, a person can simultaneously maintain both a narcissistic libidinal cathexis and a grasp on reality. Narcissistic and hysterical patients often ignore the realities and limitations of a truly human relationship and project onto the therapist idealized views of longing and desire. The equilibrium between idealization of the therapist and protecting against fragmentation and rage can exist as long as the patient can sustain the feeling that he has united with the idealized therapist (12).

In the earliest stages of therapy, the patient may describe dreams and fantasies which represent specific resistances to the development of transference. Kohut states that at this early stage in therapy it is merely important to point out the existence of these resistances and avoid premature transference interpretations which the patient would understand as prohibitions or expressions of disapproval. The working through phase of the therapy begins only after idealizing transference has been established. In typical transference neuroses, the object of the therapy is to expand the ego's understanding of instinctual libidinal objects, and admit these desires into the conscious realm. In Kohut's self-psychology, the working through process concerns the ego's reaction to the loss of the narcissistically-experienced object. Kohut gives us a deeper understanding of the highly eroticized transference which can occur. He states that the perversions which the patient may fantasize with the therapist can be "viewed metapsychologically as the deeply frightening feelings of fragmentation and deadness which the (patient) experiences as a manifestation of 
... the absence of the narcissisticly invested self-objects ... thus are attempts to reestablish the union with the love object through visual fusion and other archaic forms of identification". By careful inquiry into the disappointments and feelings regarding the love and the erotic fantasies toward the him, the therapist will increase the patient's ego's ability toward sublimation. The time between appointments, reinforces the patient's maintenance of a part of the investment in the self-object, the therapist, with idealizing cathexes despite the external separation from him. Toleration of the therapist's inquiries allows the patient to see that his range is not destructive to the therapist nor is it consuming of himself (12).

The following case example shows how transference love, improperly technically handled, can promote acting out behavior in the patient.

\section{CASE EXAMPLE 2}

Mrs. J. is a 34 year old married woman who presented to the psychiatry clinic because of marital problems. She had been married for three years and felt her husband was no longer paying attention to her. Despite a prior course of antidepressant therapy, her sleep worsened, her appetite fluctuated and she worried about the possibility of divorce. She felt unable to talk to her previous psychiatrist about her problems. She was an attractive, articulate and intelligent successful executive who appeared in control of her life. During the initial part of the therapy, Mrs. Jones participated well in treatment; seemed to develop insight quickly and was open to clarifications and interpretations. Her sleep and appetite improved. When Mrs. J.'s husband asked for a divorce, she declared her love for the therapist: "No one in my life has paid so much honest attention to me and my problems. I've found that my husband is not worthy; you are." Over the next few sessions, the therapist pointed out she was replacing one love relationship with another and that her high expectations were responsible for the poor outcome of her important relationships. Mrs. J. became quieter and stated she felt she had learned enough from therapy. She called to cancel the last scheduled session stating that her lawyer's appointments took precedence. She had decided to contest the preliminary alimony arrangements. "It looks like I'm going to have to really hurt him in court," she said.

Note how the therapist's quick interpretation, which focuses on the patient's failings, precedes the displacement of anger towards the husband and the termination of therapy. Early inquiry into the feelings of the patient towards the therapist may have been more helpful; perhaps the therapist was uncomfortable with the patient's declared love feelings.

\section{COUNTERTRANSFERENCE LOVE}

Annie Reich, in a classic piece of literature, describes countertransference as "the effects of the analyst's own unconscious needs and conflicts on his understanding or technique. The patient represents for the analyst an object of the past on to whom past feelings and wishes are projected" (13). A simple declaration of like or dislike for a particular patient is not an interpretation of countertransference. Therapists develop a relationship with each and every patient much of which is influenced by previous relationships. Indeed, the ability to understand what a particular patient is saying and to respond in an empathic manner is the skill of therapy. The therapist 
may dip into the well of countertransference, and return to the surface of the here-and-now with an empathic understanding of that individual. To stay in the well is to identify with the patient and carries the danger of using the therapeutic process to gratify the therapist's own needs.

Countertransference may sustain and invigorate work with patients because of the dynamic interchange which occurs with patients, or it may lead to acting out on the part of the therapist. The slow, cumbersome process of therapy make high demands on the therapist's patience and narcissistic equilibrium. The psychic energy needed to maintain interest and willingness to help springs from this same countertransference well. As Dr. Reich put it, "special talent and the pathologic are usually two sides of the same ... a slight shift in cathexis may transform acting out into valuable sublimation". The wish to heal and understand may be motivated by the past, but the therapist's insight and treatment must be based on objective reality. The therapist uses his or her own feelings to make therapy work. But love, like aggression, guilt or any feeling, must be desexualized and sublimated (13).

When does countertransference become inappropriate? Any instance of feeling preoccupied, being unable to associate freely or shrinking from certain topics are good signs. The crucial question the therapist needs to ask is "Am I doing or saying this to alleviate my anxiety and will it encourage the patient to suppress theirs?" Consultation with a colleague may help to clarify the answer; if it is "Yes," then countertransference is hindering the therapy.

The countertransference hinted at in Case Example 3 is clearly seen in the following case of a therapist who experiences being abandoned by her patient.

\section{CASE EXAMPLE 3}

A female therapist began treatment with Mrs. P., a 42 year old woman who presented with complaints of long-standing depression and "distance" in her significant relationships. She was a well-known professional in her community, receiving many awards and contributing greatly to her field of expertise. She married a man to who she had been able to tell her life's secrets. She told him of her disappointments and difficulties in growing up and the absence of love which had plagued her childhood. During arguments, Mr. P. would threaten to tell her friends and colleagues about her shortcomings and would mock his wife's dreams of the idyllic life she had hoped to share with her husband.

Mrs. P.'s mother was often absent from home due to many civic and community activities, taking a leading role in a number of women's issues on both the local and state level. Her father was often depressed. He was the caretaker of the house, and as Mrs. P. saw it, was obedient to his wife's demands and schedules, taking secret pleasure in being married to this prominent and famous woman. Mrs. P. said, "He seemed to live for my mother and not have any regard for a life of his own. When I had problems, I could go to my father, but my mother was never there for me when I needed her. I was like my father in believing that the work she was doing was all-important."

From the descriptions of her current life, it became clear that Mrs. P.'s professional activities were for the recognition from a mother who was unavailable in younger life. She recalled no sadness or tears at her mother's funeral, but rather a sense of despondency and a need to look strong in front of other family members. On the fifth anniversary of her mother's 
death, Mrs. P. felt more depressed than usual. She valued her mind as her most important tool and she was afraid she was losing it. She initially resisted seeing a psychiatrist, but trusted in the professionalism of her therapist. She looked toward the therapist as a friend and colleague in the exploration of her motivations and drives. Early clarifications elicited responses from Mrs. P. that threatened the therapist's feeling of control of the therapeutic situation. Mrs. P. talked about childhood friends to whom she confided and then felt betrayed. The dreams she related were about death and loneliness. The therapist surmised that Mrs. P. was dealing with issues of intimacy in the therapy which caused early childhood issues to resurface and was angered by her resistance to interpretations.

Mrs. P. felt the therapy was going nowhere and often missed sessions. She felt there was no use trying to dig up past memories and, although her mother had deficiencies, she was a good woman. The therapist cajoled Mrs. P. to come to the sessions and spent her own personal therapy time searching for an explanation of why she felt she had disappointed Mrs. P. or even failed her. In supervision, the therapist struggled with understanding the missed appointments and resistances to interpretations of the transference neurosis. She had difficulty realizing that Mrs. P.'s attachment to her was deeply emotional and that she might feel threatened by her tender feelings toward her therapist. Optimally, the task of the supervisor was to encourage the therapist to accept the patient's fond feelings neutrally and inquire into their meaning. During the infrequent sessions, the therapist did inquire into Mrs. P.'s concerns about the therapist and the therapy. Mrs. P. stated her problems had nothing to do with the therapy and, as usual, she was left to solve her own problems. The therapy ended without an exploration of the transference neurosis.

Note that the therapist attempted to change the course of the therapy when, in supervision, she discovered the existence of significant countertransference feelings which enabled her to see the transference love phenomenon. Often, an exploration of the transference neurosis/transference love is difficult and full of resistance, especially in a context where the patient and therapist are the same sex. The therapist seems to have entered into a "trap" in which the patient rejects her therapist's interpretations because of fears of intimacy.

\section{SUPERVISION}

Avoiding various countertransference traps is largely the task of supervision for the beginning therapist. The supervisor who is aware of transference love and who knows how to clinically use it, can help residents and other colleagues be effective with patients. Indeed, Freud states rather boldly that disregard for the concept of transference love held back the development of psychoanalytic therapy during its first decade (15). Since Freud attributed the concept of transference love to hysterical illness, he was referring to the heterosexual relationship that exists between patient and therapist. However, in the transference mode, past memories are enacted within the therapeutic relationship and may not have any regard for gender. The patient may find him- or herself distressed by feelings of sexual longing experienced for the therapist of the same gender and may screen feelings and thoughts, or opt out of therapy. It may be that the patient's ability to describe feelings of love towards the same-sex therapist is a direct function of the therapist's ability to tolerate the fear of homosexual involvement. Optimally, the task of the supervisor would be to encour- 
age the resident to accept the patient's fond feelings neutrally by inquiring into their meaning and avoiding always physical intimacy. The therapist's own therapy or analysis may help to elucidate the unconscious wishes and fantasies which can hinder treatment.

In Case Example 4, we see how the therapist's own psychological issues block the progress of treatment until supervision encourages the therapist to be more accepting of the patient's faults.

\section{CASE EXAMPLE 4}

Mrs. J.G. is a 52 year old widowed female suffering from a chronic generalized anxiety disorder. She has been followed in the psychiatry clinic for four years and was recently transferred to a new third year resident. The patient is well known to the clinic staff and is often the topic of case conferences because of her frequent phone calls and unappointed visits. She carries the additional diagnoses of dysthymia and histrionic personality disorder.

In an attempt to decrease acting out behavior, the resident began to set firm limits about appointment times and phone calls. The behaviors subsequently worsened and the resident felt increasingly frustrated. Additional supervision was sought which focused on an exploration of countertransference. The resident noted angry feelings towards the patient and a sense of incompetence and failure. As the resident began to understand that his own angry feelings were in response to the patient's ineffective means of currying acceptance-the resident himself experienced his mother as both intrusive and needy-he was able to more clearly analyze the transference data presented by the patient. Within eight weeks, telephone calls and unannounced visits subsided, and the resident expressed a relief of anxiety. Issues of intimacy with the therapist were discussed in the middle phase of therapy aided by the therapist's neutral, but warm interest in the patient's concerns. A planned termination was accomplished six months later.

Countertransference love can also be present in the work with children. In the following case, the therapist strongly identifies with her need to mother her patient/ child and is able to use these feelings constructively.

\section{CASE EXAMPLE 5}

Charlie, the patient, is a 3-year old, tow-headed boy admitted to the hospital for failure-to-thrive. His mother, a woman about the therapist's age, had been depressed and overwhelmed since the birth of Charlie's little sister five months previously. Since that time, Charlie had become withdrawn, ate very little and fell off his normal growth curve. The therapist found herself in repeated confrontations with the Child Protective Services as they attempted to remove Charlie from the home. She found it difficult to visit Charlie in his hospital room and interact with him as he stared at the television from his caged crib. She withdrew, feeling demoralized and questioning the validity of her role as a psychotherapist.

In supervision and her own personal therapy, the therapist was able to tease out how her own unconscious wishes to be the loving mother had been threatening to trap her in the countertransference well. She recognized her desire to take Charlie home and feed him correctly had inhibited her facilitation of the work of Child Protective Services and further arrangements for the treatment of Charlie and his mother. 


\section{SUMMARY}

Important clinical concepts, transference love and countertransference love, have been given little attention in recent years. It has been perhaps obscured by the difficulties of managing the often uncomfortable feelings of love between patient and therapist in the therapeutic relationship. Generally, the following guidelines can be proposed:

1. Therapeutic advance in psychodynamic therapy may not be possible without an experience of love in the therapeutic relationship. However some patients may not be able to tolerate the direct interpretation of their idealization or love of the therapist. Caution and sensitivity must be used.

2. The therapist is bound by an ethic of restraint in response to the therapeutic contract of unfiltered sharing of thoughts and emotions by the patient.

3. Feelings of love arising in the therapist need to be sorted through as a countertransference issue with the supervisor or consultant. This enables the therapist to more objectively explore issues of intimacy with the patient.

\section{REFERENCES}

1. Freud S: Introductory Lectures on Psychoanalysis, in Standard Edition, London, Hogarth Press, 12: p. 159, 1971

2. Glover E: The Technique of Psychoanalysis, New York, International University Press, Inc., p. 111, 1955

3. Freud S: Standard Edition, 12:162-167, 1971

4. Eickhoff FW: A short annotation to Sigmund Freud's observation on transference love. International Review of Psychoanalysis 14:103-109, 1987

5. Freud S: Observation on Transference Love, in Standard Edition, London, Hogarth Press, 16:431-463, 1971

6. Rappaport SA: The management of an eroticized transference. Psychoanalytic Quarterly 25:515-529, 1956

7. Kepecs J: Theories of transference neurosis. Psychoanalytic Quarterly 35(4):497-52 1, 1966

8. Fenichel O: Problems of Psychoanalytic Technique, New York, The Psychoanalytic Quarterly, Inc., p. 505, 1941

9. Alexander F, French TM: Psychoanalytic Therapy, New York, The Ronald Press Co., p. 17, 1946

10. Freud S: Standard Edition, 12: p. 165, 1971

11. Kohut H: The analysis of the self. in The Psychoanalytic Study of the Child, New York, International Universities Press, Inc., 4: p. 80, 1971

12. Kernberg O: Borderline Conditions and Pathological Narcissism, New York, Jason Aronson, pp. 276-282, 1975

13. Reich A: On counter-transference. International Journal of Psychoanalysis 32:25-31, 1951

14. Winnicott DW: Hate in countertransference. in DW Winnicott: Collected Papers, London, Tavistock Publications, p. 196, 1958

15. Freud S: Standard Edition, 12: p. 1959, 1971 